\title{
Powder and Solvent for Implantation Paste Dosage Form
}

National Cancer Institute

\section{Source}

National Cancer Institute. Powder and Solvent for Implantation Paste Dosage Form. NCI

Thesaurus. Code C149784.

Sterile powder and sterile solvent intended for the preparation of an implantation paste by dispersing the powder in the solvent. 